International Journal of Linguistics, Literature and Translation (IJLLT)

ISSN: 2617-0299 (Online); ISSN: 2708-0099 (Print)

DOI: $10.32996 / \mathrm{ijllt}$

Journal Homepage: www.al-kindipublisher.com/index.php/ijllt

IJLLT

\title{
Translation Strategies of Idiomatic Expressions in The Novel Edensor
}

Alfiana Asti Premasari ${ }^{1 *}$ and Pratomo Widodo ${ }^{2}$

${ }^{12}$ Yogyakarta State University, Indonesia

Corresponding Author: Alfiana Asti Premasari, E-mail: alfianaasti.2018 @student.uny.ac.id

ARTICLE INFORMATION

Received: December 22, 2020

Accepted: February 14, 2021

Volume: 4

Issue: 2

DOI: 10.32996/ijllt.2021.4.2.9

\section{KEYWORDS}

Figurative language, Idiom, Translation technique, Translation strategy, Translator credibility

\section{ABSTRACT}

The objective of this research is to investigate (describe) the strategies in translating idiomatic expressions in the Novel Edensor and the problems on the translation process. As a result, the similarities of the idioms of the source text and the target text were found. Besides, this study was aimed at improving the knowledge about idiom varieties between the source text and target text. This is a qualitative study. It is a hermeneutic study that is an approach which concerns with social issues on written words. The non-participant observation was the technique to collect data. The technique for analyzing the data was translational identity method and the referential identity method. It was also the technique to measure the validity and reliability of the data. The data were identified, classified, and categorized based on the types of idioms and the translation techniques. The findings were 120 expressions identified in the novel, however, the translator found $25 \%$ of expressions, and $75 \%$ of them were translated, with five translation procedures: similar meaning and dissimilar form was the procedure that mostly applied in the novel of $47.25 \%$, dissimilar meaning and the similar form of $35.16 \%$, and $13.18 \%$ of paraphrasing technique $3.29 \%$ was of omission, and $1.09 \%$ of borrowing. The procedure that was implemented gave an impact on the type of idioms. The specific procedures were applied to keep the originality of the source text information and the credibility of the translator. The translation strategy was communicative. It was supported by rearrangement in some chapters and topics

\section{Introduction}

The novel Edensor that was written by Andrea Hirata that included idiomatic words, phrases, and sentences that are difficult to be interpreted. Translators have to understand the definition of units of words, which is a kind of challenge for any translator in translating idioms. There are two translation strategies and methods, according to Munday \& Hatim (2004, pp. 10 - 12), which are literal and free translation then, form, and content. The procedures are divided based on the methods, for example, literal translation has direct methods, and the procedures are literal, borrowing, and calque, while in free translation strategy, the method is oblique. One example of the procedures is the equivalence that is delivering the message in different ways, such as the proverb that is translated in a form of a statement. This research investigates the strategy of translating idiomatic expressions in novel Edensor, keras kepala.is translated as 'so stubborn.' Matanya yang bening, that means his cloudy eyes. ..Hatiku ngilu becomes my heart stung' kasih tak sampai.. is traversed to unreachable love (Hirata, 2007) are some examples of the idioms.

The problems in translating idioms are semantic and pragmatic. This study focuses on the pragmatic aspect of the translation. It concerns on the theory that idioms are identical with cultures of a society. The phrases might not be translated literally and will cause misunderstanding, miscommunication, and the translation results become weird, or in other words, the translation is unreadable, cannot be understood, or even the meaning is different from that of the source language. (Dell \& McCarthy, 2010; KEMENDIKBUD, 2017; O'dell \& Mc Charity, 2010; Oxford University, 2002; Panicked Teacher, 2011; Samuelesson, 2013) A professional translator is required to translate idioms as comprehensive knowledge and skills which are needed to minimalize errors. The translator of the novel Edensor was the leader of Uber Company and an English teacher in Indonesia from the USA. He was fluent in Indonesian and Javanese languages. However, the translator's background of education and other translation

K C AL-KINDI CENTER R D FOR RESEARCH AN Your gateway to world-class research

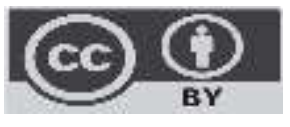

Published by Al-Kindi Center for Research and Development. Copyright (c) the author(s). This open access article is distributed under a Creative Commons Attribution (CC-BY) 4.0 license 
products were not mentioned (Kurniawati, 2017). It is related to the translator's credibility those are the reasons why translating idioms is an interesting research topic.)

\section{Literature Review}

An idiom is a phrase that consists of two or more words whose meanings cannot be understood literally but contextually (Smolinski 2010; Dell \& Mccarthy, 2010). KEMENDIKBUD (2017) stated that idioms are different construction between word and meaning. They also define a specific language of a society. An idiom is a group of words established by a usage as having a meaning not deducible from those of the individual words. An idiom also defines as a form of expression natural to a language, person, or group of people, or the dialect of a people or part of a country. Many definitions of idiom are taken from (Oxford, n.d.). It is similar to the definition by the Indonesian Dictionary, that it is a natural specific language of a society, which is also known as a dialect. Newmark (2001, p. 125) stated that an idiom could never be translated word to word, and usually, the difficulty is found in the form of the term. Crane via Newmark (2001, p. 126) argued that the translator should discover an idiom in the target language which has a similar meaning to the idiom in the source language.

However, Glucksberg (2001, p. 75) stated that one of the varieties of idiom, the meaning of idiom can be identified, it defines as compositional transparent. For example, "spill the beans" which literally means spreading beans in the wrong place. It illustrates the situation of telling a secret. The meaning of idiom can be identified based on language structures. The type that is not transparent is called non-compositional. There is no relationship between language structure and the meaning. Lemon law is an example, and the meaning of lemon is a fatal mistake that cannot be improved. Then, compositional opaque is the meaning of the statement which has more than one meaning; for example, "kick the bucket" which can be defined as a discrete or swift action. The last is queasy metaphor, which is an opinion about someone/something based on prototype and stereotype. 'My job is a jail' is one example. Accordingly, metaphor and simile are varieties. An idiom is the high level of collocation while collocation is a unit of word relation, giving notion that the meaning of an expression still can be identified by the meaning of each word. However, idiom must be translated as a unit of words (Baker, 2018, pp. 59-69). The phrase "dry cow" means a cow that cannot produce milk. The phrase can be identified word for word. A cow usually produces milk, but the word "dry" indicates the cow is not able to produce. It is an example of idiom definition by Baker.

Translation strategy is a mental process when treating a text. In other words, it is the process of deciding the most appropriate translation technique (Bardaji \& Bardaji, 2009, p. 162) and (Lörscher, 1991, pp. 68-81)). The considerations in translating idioms are understanding region characteristics (Brenner, 2003, p. 13). Translators should recognize what makes each country wellknown, which makes them internalize the tradition of the countries, and therefore they can decide the best translation strategy, and hence the translation product is accurate and acceptable. The strategy which is used depends on the language orientation. From the orientation, it is called as translation ideology. It can be identified, Venuti (2017, pp. 99-100) and Tanjung (2018, p. 15) stated two translation ideologies. The first is domesticating, which means the translation orientation is the target language, the foreignizing strategy emphasizes the identity of the source text. Newmark (2001, pp. 38 -39) had different name for the strategies there are semantic and communicative. Based on the definitions, idiom is a combination of word with a new meaning which is different from the conventional meaning that relates to society and cultures (Dell \& Mccarthy, 2010; KEMENDIKBUD, 2017; O'dell \& Mc Charity, 2010; Oxford University, 2002; Panicked Teacher, 2011; Samuelesson, 2013). Collocation, personification, and simile are the figurative languages included in idiom types (Panicked Teacher, 2011; Spivey \& Ed, 2011)

Translation procedure is a specific technique to solve problems of translation after deciding the language orientation. (Sun, 2013, pp. 2-3). Baker (2018, pp. 77,80$)$ named the translation procedure as 'translation strategy'; they are borrowing, and similar meaning and form that the same as a literal translation by Munday (2016: 89). Idiom(s) cannot be translated literally, so the message is important than the language structure. It is similar to adaptation procedure from Munday (2016, p. 91) or having similar meaning but the form is different. Baker (2018, pp. 79 - 86) also translates idioms with omission and paraphrasing. She also has a paraphrasing strategy to translate idioms. It is similar to explication, which translates the idioms into a clear meaning (Baker \& Saldanha, 2011, p. : 36).

The translation process is where the translation category is used to translate the idioms. There are: metaphase, which is the word for word technique; paraphrase, which to keep in the point of view of the source text, and imitation/adaptation, which is recreating new expressions with the source topics (Munday, 2016, p. 43).

\section{Methodology}

The type of this research is hermeneutic qualitative. The data were idioms that was provided from a popular novel that has two versions in two languages. the researcher is the observer, who does not participate in society. The researcher can be the 
instrument after preparations, such as understanding the issues that will be investigated and mastering the theories, data collection techniques, and data analysis technique. Types of idioms from Samuelsson (2013) as the parameter

The researchers included all original data, note-taking, or making drafts which were then debriefed by the supervisor. The validity was also checked by using referential identity method. The idioms that had been classified were compared to idiom dictionaries. If that is in the dictionaries, and if the phrases do not exist in the regular dictionaries, it means the data are valid

The data are translated directly. If it is meaningless or if the translation result is uncommon, the data were translated indirectly. The steps are word for word, literal, semantic, communicative, and free translation. The strategies are identified based on translation techniques. Based on the theory from Dryden via Munday (2016) literature work categorizes as a free translation approach. In that way, the techniques follow the approach. In another word, the data analysis techniques are the referential identity method and translational identity method

\section{Results and Discussion}

The results of the study is presented and disscussed below.

Table 1: Data Percentage

\begin{tabular}{|l|l|l|l|l|}
\hline Data & Translated & Percentage & Not translated & Percentage \\
\hline 120 & 91 & $75 \%$ & 29 & $25 \%$ \\
\hline
\end{tabular}

The translator simplified the English version. Prolog in Chapter 1 did not exist in the version. Chapter 21 which compared Roma Irama and Adam Smith was not translated. The English version was focused on the main characters. The consequences in Chapter 43 were deleted. It told about classmates. It affected the idiom quantity in the target language.

Table 2: Idiom Type Percentage Based on the Meaning (Fernando,1996)

\begin{tabular}{|l|l|l|l|l|l|}
\hline No. & Type & ST Frequency & $\begin{array}{l}\text { TT } \\
\text { Frequency }\end{array}$ & ST Percentage & $\begin{array}{l}\text { TT } \\
\text { Percentage }\end{array}$ \\
\hline 1. & Pure & 38 & 28 & $40.65 \%$ & $30.76 \%$ \\
\hline 2. & Semi & 39 & 22 & $41.75 \%$ & $24.17 \%$ \\
\hline 3. & Ideational & 9 & 5 & $9.89 \%$ & $5.49 \%$ \\
\hline 4. & Interpersonal & & & $5.49 \%$ & $39.56 \%$ \\
\hline 5. & Literal & 5 & 36 & & \\
\hline
\end{tabular}

The idiom types were changed due to the translation procedures. The purpose is to keep the originality of the information and to make the readers not feel the novel as a translation product. On the other hand, the translator was not an expert in translating idioms, due to the background as an English teacher. He avoided mistakes, then prefers to translate the idioms in a different form.

Table 3: Translation Procedure /Techniques, Strategy, and Process Frequency (Baker, 2018; Newmark, 2001; Munday, 2016)

\begin{tabular}{|c|c|c|c|c|c|}
\hline Procedure & Code & Frequency & $\begin{array}{l}\text { Percentage } \\
(\%)\end{array}$ & Strategy & Process \\
\hline Similar meaning and form & SMF & 32 & $35.16 \%$ & $\begin{array}{l}\text { Foreignizing } \\
\text { \semantic }\end{array}$ & Literal \\
\hline Similar meaning but dissimilar form & SMDF & 43 & $47.25 \%$ & $\begin{array}{l}\text { Domesticating/ } \\
\text { communicative }\end{array}$ & $\begin{array}{l}\text { Literal, } \\
\text { paraphrase \& } \\
\text { adaptation }\end{array}$ \\
\hline Paraphrase & $P$ & 12 & $13.18 \%$ & $\begin{array}{l}\text { Domesticating/ } \\
\text { communicative }\end{array}$ & $\begin{array}{l}\text { Literal } \\
\text { \&paraphrase }\end{array}$ \\
\hline Borrowing & B & 1 & $1.09 \%$ & $\begin{array}{l}\text { Foreignizing } \\
\text { semantic }\end{array}$ & \\
\hline Omission & $\mathrm{O}$ & 3 & $3.29 \%$ & $\begin{array}{l}\text { Domesticating/ } \\
\text { communicative }\end{array}$ & $\begin{array}{l}\text { Literal \& } \\
\text { paraphrase } \\
\text { adaptation }\end{array}$ \\
\hline
\end{tabular}


Table 3 describes that the strategyies applied were related to the procedures. The idioms were translated with the communicative strategy. The percentage of the procedures was the evidence. SMDF of $47.25 \%$, paraphrase of $13.18 \%$, and omission of $3.29 \%$. These procedures were in the category of communicative translation. On the other hand, the semantic strategy was SMF of $35.16 \%$ and Borrowing of $1.09 \%$. However, the translation procedures did not always represent the translation strategy. The example is shown in Table 4

\section{Translation Process}

The translation process was one step to create an accurate idiom. A case 'bekerja keras' became 'busily working'. 'Bekerja keras' can be translated literally, 'bekerja' is equivalent to 'work' and, 'hard' is equivalent to 'keras'. However, the idiom became 'busily working'; the consideration is the sense of the event. The feeling of 'busily working' was more than work hard. Accordingly, the translation process of 'bekerja keras' is literal (bekerja = work = keras=hard) to (bekerja = working, keras = busily) adaptation.

Table 4: Translation Process Examples

\begin{tabular}{|c|c|c|c|c|c|}
\hline Source Text & Target Text & Strategy & Procedure & Process & Types \\
\hline ciut nyalinya, & shrink back- & Communicative & SMF & $\begin{array}{l}\text { Shrink back=Break out in } \\
\text { the cold sweat }\end{array}$ & $\begin{array}{l}\text { Semi idiom - } \\
\text { pure idiom }\end{array}$ \\
\hline Uang saku & Allowance & Semantic & SMDF & $\begin{array}{l}\text { Uang saku is similar to } \\
\text { pocket money }\end{array}$ & $\begin{array}{l}\text { Semi idiom - } \\
\text { literal idiom }\end{array}$ \\
\hline Orang udik! & You boor! & Communicative & SMDF & $\begin{array}{l}\text { The definition is a } \\
\text { rude/impolite/tacky person. }\end{array}$ & $\begin{array}{l}\text { Semi Idiom pure } \\
\text { - idiom }\end{array}$ \\
\hline $\begin{array}{l}\text { Sebatang } \\
\text { kara }\end{array}$ & $\begin{array}{l}\text { Alone, without } \\
\text { relatives }\end{array}$ & Semantic & $P$ & $\begin{array}{l}\text { The idiom 'sebatang kara' } \\
\text { was changed into the } \\
\text { definition. }\end{array}$ & $\begin{array}{l}\text { Pure idiom - } \\
\text { literal idiom }\end{array}$ \\
\hline $\begin{array}{l}\text { pagi buta, } \\
\text { kami bertolak }\end{array}$ & $\begin{array}{l}\text { We pushed off in } \\
\text { the early morning } \\
\text { and } \\
\text { southeast }\end{array}$ & Communicative & $P$ & In the early morning/ & $\begin{array}{l}\text { Semi idiom - } \\
\text { literal idiom }\end{array}$ \\
\hline
\end{tabular}

The strategy of the first example is communicative, but the procedure is similar in meaning and form. The message was transferred in a different type of idiom with a similar language structure. The second example was translated semantically. 'Uang saku' was equivalent to 'pocket money', but the word choice was 'allowance'. The meaning of the word is predictable, but the phrase structure between the ST and TT was not the same. In the third case, 'orang udik' can be identified as semi-idiom based on the language structure, but the word 'orang' is equivalent to 'a person' and 'udik' describes a bad attitude person. Regarding the meaning, it was an ideational idiom as the word 'udik' was a swear word to express negative emotion.

The paraphrasing procedure is between literal and free translation strategies (Munday, 2016, p. 43). It can characterize the semantic or communicative strategy. 'Sebatang kara' became 'alone without relatives' as shown in Table 5 number 4 represents a semantic strategy. The phrase cannot be translated literally. However, in the data on number 4, which is 'pagi buta', each word has a synonym in the target language. Although the phrase cannot be translated literally, the message did not transfer well. Thus, the idiom was paraphrased, and briefly the strategy was communicative.

In the original version of the novel, there were 120 idioms found. However, in the English version, the idioms were only 91 . The Indonesian version consists of 43 chapters and 196 pages. The translator applied the adaptation technique in the English version. That consists of 40 chapters and 238 pages. The chapters' sequence and topics were rearranged. The Pathetic Four in the original is in Chapter, 17 but in the English version, it is in Chapter 16. Chapter 19 is in the arrangement of 19 and 20 of the original. One paragraph was also lost in Chapter 19 and Chapter 28 in the English version of Chapter 30 in the original. Chapter 21 in the original version, which is entitled Adam Smith vs Rhoma Irama, is not found in the English version. It affected the data quantity between the source language and the target language which were different. The topic of the chapters is also changed. Chapter 15 in the original title is Aku dan Anggun C. Sasmi, while in the English version becomes Paris. Chapter 11 of the original title is John Wayne because he is the main character. However, in the English version, the title is Brugge, the place where the story happened. In Chapter 21 of the original version is entitled Helium, but the English version is Are You for Real? in chapter 20. This part staes that the main character of this novel experiences an unbelievable event and it is similar to inhale helium, and it makes it hard to breathe. This communicative translation strategy decreases the idioms in the target language. Briefly, the 
translator applied the omission and loss gain procedure. The data show that communicative translation is the principle of the English version of novel Edensor. The strategy that was mostly used was 'similar meaning and similar form' of $47.25 \%$ and $35.16 \%$ 'for similar meaning but dissimilar form.' The paraphrasing procedure was $13.18 \%$. The percentage of omission procedures was $3.29 \%$, and the lowest frequency was borrowing strategy, which is $1.09 \%$

\section{A. The findings of research question 1. What were the translation strategies that used in translating idiom?}

1. The translation strategy was communicative (63.72\%). The translator did not translate idioms into idioms frequently. He focused on delivering the original information. As stated by Newmark (2001, p. 39), communicative translation concerned the effect of the information on the readers.

2. The previous relevant studies investigated the procedures of idiomatic translation based on the theory from Baker (2018), namely borrowing, omission, similar meaning and form, similar meaning but dissimilar form, and paraphrase. This research used the same theory to identify the translation strategy of the novel. Omission, similar meaning but dissimilar form, and paraphrase were the most

3. The shifting of the type of idioms between the source language and the target language also gave the sign of the translation procedures. It hinted at the translation strategy and translation procedures. The theory of idiom type was cited from Samuelsson (2013, pp. 14-15), namely pure idiom, semi-idiom, literal idiom, ideational idiom, interpersonal idiom, and relational idiom. A pure idiom can be a literal idiom, and the translation procedure was a paraphrase.

4. The translation process of the idioms referred to Dryden via Munday (2016), the steps are literal translation, free translation, and adaptation.

\section{B. The findings of research question 2: Why did the translator apply specific translation techniques?}

1. The sense of culture is an important factor in translating idioms. It causes the culture of a country a consideration (Bardaji \& Bardaji, 2009; KEMENDIKBUD, 2017). The ideas of idioms must be transferred although in a different form (Tanjung, 2018: 3). The theory was the foundation of selecting specific translation procedures that affected the type of idioms.

2. The translator's knowledge and experience influenced the translation process and the translation product. The probability of the level of naturalness was higher if the translator was a professional. On the contrary, idiomatic translators should not be translators although the translation product is not always equivalent in the form as the source language.

\section{Conclusion}

The essential issue in this research is the translator of the novel Edensor who was the leader of Uber Company and an English teacher in Indonesia from the USA. He was fluent in Indonesian and Javanese languages. However, the translator's background of education and other translation products were not mentioned (Kurniawati, 2017). It is related to the translator's credibility in choosing the strategy of translation. It was related to the research objective, which investigated idioms translation strategy He might not understand the specific cultures of idioms because he was a nonnative speaker. He might only stay in some regions in Indonesia. Foreigners are commonly fluent in the official language only.

The translator combined 5 translation strategies and 9 translation techniques to defend the text accuracy, naturalness, and readability. In conclusion, the translation strategy that is applied to translate the idioms is communicative, with the procedures of similar meaning, dissimilar form, or adaptation technique. The translation techniques that were applied affected the types of idioms. Thus, the translator wanted to deliver the original messages of the novel although in different types of idioms. Furthermore, the experience and the background knowledge of the translator showed his credibility

Funding: This research received no external funding

Acknowledgments: I would like to thank the examiners and the supervisor for the suggestions and revision for this article.

Conflicts of Interest: The authors declare no conflict of interest 


\section{References}

[1] Baker, M. (2018). In Other Word (Third edit). New York: Routledge.

[2] Baker, M., \& Saldanha, G. (2011). Encyclopedia of Translation Studies. (M. Baker \& G. Saldanha, Eds.) (2nd ed.). Londom and New York: Routledge.

[3] Bardaji, A. G. (2009). Procedures, techniques, strategies: Translation process operators. Perspectives: Studies in Translatology, 17(3), 161-173. https://doi.org/10.1080/09076760903249372

[4] Brenner, G. (2003). Webster's New World American Idioms Handbook. Indiana, Canada: iley Publishing, Inc. Retrieved from https://s103.nitroflare.com/d/da231fb78f4238d71f97fe0fc10b16db/Webster's New

[5] Dell, F. O., \& Mccarthy, M. (2010). What are idioms?, 6-15. Retrieved from http://assets.cambridge.org/97805217/44294/excerpt/9780521744294_excerpt.pdf.

[6] Glucksberg, S. (2001). Understanding Figurative Language. New York: Oxford University Press Published.

[7] Hirata, A. (2007). Edensor. (I. Risdiyanto, Ed.) (Fifth Edit). Yogyakarta: Bentang Pustaka.

[8] KEMENDIKBUD. (2017). Kamus Besar Bahasa Indonenesia. Retrieved October 9, 2018, from https://kbbi.kemdikbud.go.id/entri/idiom

[9] Kurniawati, R. (2017). John Colombo, Bos Uber yang Ingin Indonesia Dikenal karena Buku. Appler.Com. Retrieved from ttps://www.rappler.com/indonesia/ayo-indonesia/170242-john-colombo-uber-indonesia-hari-buk

[10] Lörscher, W. (1991). Translation Performance, Translation Process, and Translation Strategies: A Psycholinguistic Investigation. Tubingen: Gunter Narr.

[11] Munday, J. (2016). Introducing Translation Study. (4th, Ed.). Londom and New York: Routledge n nb.

[12] Munday, J., \& Hatim, B. (2004). Translation An Advanced Resource Book (1st ed.). Londom and New York: Routledge.

[13] Newmark, P. (2001). Approaches to Translation. New York: Pregamon Press.

[14] Oxford. (n.d.). English Oxford Living Dictionary. Retrieved March 13, 2019, from https://en.oxforddictionaries.com/definition/idiom

[15] Panicked Teacher. (2011). What is Figurative Language? Retrieved from https://www.anderson1.org/cms/lib04/SC01000609/Centricity/Domain/377/figurativelanguagekit.pdf.

[16] Samuelesson, M. (2013). Figurative Language -, (Pedagogy). Retrieved from http://www.divaportal.org/smash/get/diva2:600646/fulltext01.pdf

[17] Smolinski, M. A. M. and S. (2010). IN THE LOOP Guide to American English Idioms. Washington: Office of English Language Programs United States Department of State. Retrieved from englishprograms.state.gov

[18] Spivey, B. L., \& Ed, M. (2011). Types of Figurative Language, (336). Retrieved from https://www.handyhandouts.com/pdf/336_TypesoffigurativeLang.pdf.

[19] Sun, S. (2013). Strategies of Translation. The Encyclopedias of Applied Linguistics. https://doi.org/10.1002/9781405198431.wbeal1117

[20] Tanjung, S. (2018). Penilan Penerjemahan Jerman - Indonesia. (Romiyatun, Ed.) (2nd ed.). Yogyakarta: Kanawa.

[21] Venuti, L. (2017). The Translator's Invisibility: A History of Translation. The Translator's Invisibility: A History of Translation.

https://doi.org/10.4324/9781315098746 